\title{
Analysis of Masonry Infill in a Multi-Storied Building Niruba $\mathbf{S}^{*}$
}

Civil Engineering Department, Erode Sengunthar Engineering College, Thudupathi, Erode, India

\begin{abstract}
In many literatures, studies show that infill's modify the behavior of framed structures under lateral loads; the contribution of panels is generally neglected in common structural analyses. The structural effect of brick infill is generally not considered in the design of columns as well as other structural components of RC frame structures. The brick walls have significant in-plane stiffness contributing to the stiffness of the frame against lateral load. The lateral deflection is reduced significantly in the infilled frame compared to the deflection of the frame without infill. It is observed that frames with infill produce much smaller deflections as compared to frames without infill. The results reflect the significance of infill in increasing the strength, stiffness and frequency, of the entire system depending on the position and amount of infilling. Lower infilling is noted to provide more stiffness for the system as compared with upper locations. A number of non-linear static (pushover) analyses were performed on proper structural models of the building, considering both bare framed structure and the infilled one, in order to appraise the influence of infill walls on the failure mechanisms. In particular, a sensitivity analysis was performed by assigning different Partial Safety Factors (PSF) to the mechanical parameters of infill walls, in order to investigate their effect on the overall structural response of the building.
\end{abstract}

Keywords: Lateral loads; Inter-storey drift ratios; Storey displacements; Stiffness, Masonry infill

\section{Introduction}

Masonry is the building of structures from which individual units laid in and bound together by mortar; the term masonry can also refer to the units themselves. The common materials of masonry construction are brick, stone, marble, granite, travertine, limestone, cast stone, concrete block, glass block, stucco, and tile. Masonry is generally a highly durable form of construction. Various advantages have been acquired on analyzing the structures with infill, they are,

- The use of materials such as bricks and stones can increase the thermal mass of a building.

- Most types of masonry typically will not require painting and so can provide a structure with reduced life-cycle costs.

- Masonry is very heat resistant and thus provides good fire protection.

- Masonry walls are more resistant to projectiles, such as debris from hurricanes or tornados.

Here also arise some of the disadvantages like,

- Extreme weather causes degradation of masonry wall surfaces due to frost damage. This type of damage is common with certain types of brick, though rare with concrete blocks.

- Masonry tends to be heavy and must be built upon a strong foundation, such as reinforced concrete, to avoid setting and cracking.

- Save for concrete, masonry construction does not lend itself well to mechanization, and requires more skilled labour than stick-framing.

In Euro code 6, six types of masonry units are defined: clay units, calcium silicate units, aggregate concrete units, autoclaved aerated concrete units, manufactured stone units and dimensioned natural stone units complied with the relevant European standards EN 771-1 to 6. However, brickwork can be combined from many of the following components: adobe, ashlars, blocks, bricks, bitumen, chalk, cement, lime and mortar. Depending on which materials are used, and how they are located, Reinforced Masonry (RM) walls can be divided into the following classes: confined masonry, reinforced cavity masonry, reinforced solid masonry, reinforced hollow unit masonry, reinforced grouted masonry and reinforced pocket type walls.

\section{Current Methods of Modeling Masonry}

Two main types of masonry models can be distinguished into: the micro- and the macro-modeling.

In case of macro-models, the brick, the mortar and the joint is one homogeneous material that represents the behavior of the masonry.

Micro-models should be used when local actions need to be analyzed deeply. In case of macro-modeling, the global behavior of the structure is analyzed by a homogeneous material, so the behavior can be described by the global properties; thus, it is not attempted to make the calculations with local failures.

\section{Effect of infill}

- The stresses, in the infill wall, however, were found to increase with the increase in Young's Modulus of elasticity [1] due to the increase in stiffness of the system, attracting more forces to the infill.

- The infill wall enhances the lateral stiffness of the framed structures; however, the presence of openings within the infill wall would reduce the lateral stiffness [1-3].

- The fundamental period only slightly increases as the infill wall thickness increases [2], since the increase in thickness only increases the mass of the structure rather than its stiffness.

- The infill was assumed to crack once the stress in the infill exceeded the ultimate compressive stress of the infill material [2].

*Corresponding author: Niruba S, Civil Engineering Department, Erode Sengunthar Engineering College, Thudupathi, Erode, India, Tel:9486825972; E-mail: nirubasn@gmail.com

Received December 20, 2013; Accepted February 26, 2014; Published March 07, 2014

Citation: Niruba S (2014) Analysis of Masonry Infill in a Multi-Storied Building. J Civil Environ Eng 4: 139. doi:10.4172/2165-784X.1000139

Copyright: (๑) 2014 Niruba S. This is an open-access article distributed under the terms of the Creative Commons Attribution License, which permits unrestricted use, distribution, and reproduction in any medium, provided the original author and source are credited. 
- The strength if infill in terms of its Young's modulus (Ei) has a significant influence on the global performance of the structure [4]. The structural responses such as roof displacements, interstorey drift ratios and the stresses in the infill wall decrease with increase in $(\mathrm{Ei})$ values due to increase in stiffness of the model.

- The opening size of the infill $[1,2,5]$ has a significant influence on the fundamental period, inter-storey drift ratios, infill stresses and the structural member forces. Generally, they increase as the opening size increases, indicating that the decrease in stiffness [5] is more significant than the decrease in mass.

- The specific weight of reinforced masonry is smaller, the thermal and somniferous conductivity of the masonry is worse and it also has better resistance against fire and chemicals.

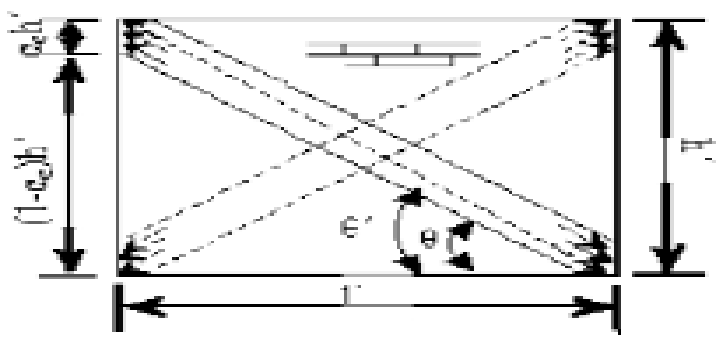

Figure 1: 'Equivalent Diagonal Strut' model for infill panel.

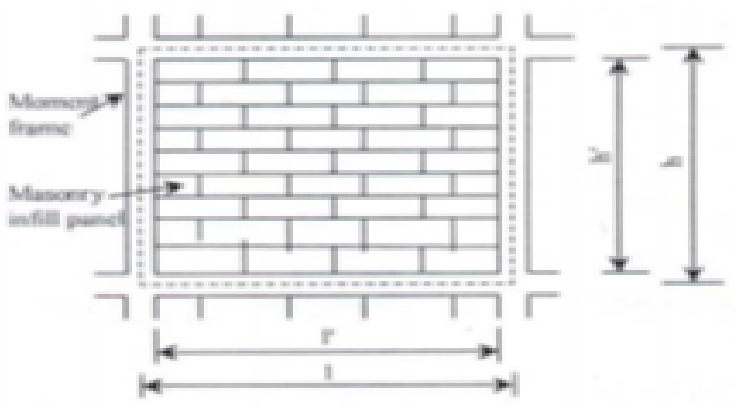

Figure 2: Masonry infill panels in framed structures.

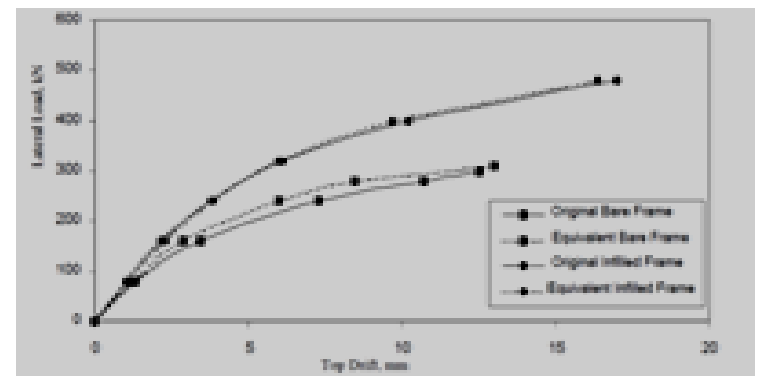

Figure 3: Load-Deflection characteristics for the original and equivalent systems.
- The wall can be loaded right after finishing the construction (Figures 1 and 2).

\section{Role of infill}

Existence of infilling is noted to increase the ultimate lateral resistance of the system while resulting in less ultimate lateral deflection for lower infilling. The effect on both parameters is more pronounced for higher percentages of infilling. Two phenomena arise through the stage of loading and result in the response nonlinearity. First is to find the stiffness degradation of the reinforced concrete with load-induced orthotrophy depending on both the applied dynamic load [2,5] and the inherent deformational characteristics of the frame. Second is to find the progressive strength reduction of either of the diagonal struts, which is supposed to be sequential according to level of loading.

Conventional half-brick wall infilling is noted to affect nearly all of the dynamic parameters [4] of reinforced concrete frames. Infill influence on the kinetic and kinematic coefficients related to lateral excitation is found to depend on frame features such as number of stories and number of bays as well as infill amount and position. Lower location yields the higher strength, stiffness, and frequency of the system. Nonlinearity of the behavior is basically due to stiffness degradation, which consequently results in frequency attenuation [4] during the loading regime (Figure 3).

The sway characteristics of building are different for frames considering infill rather than frames without infill (Table 1).

\section{Effect of opening size}

The infill wall enhances the lateral stiffness of the framed structures; however, the presence of openings within the infill wall would reduce the lateral stiffness [5]. The fundamental period increases as the opening size increases, as expected, due to reduction in stiffness of the model. Such variation of periods cannot be considered using the Code values. The fundamental period $[2,5]$ of the fully infilled model was $54.87 \%$ higher than that of the bare frame model. There is no clear relationship between the opening size and the fundamental period, but the opening size does have an influence on the fundamental period of the structure [2].

The seismic response of in-filled frame structures is,

a. The strength of infill in terms of its Young's Modulus (Ei) has a significant influence on the global performance of the structure [1]. The structural responses such as roof displacements, interstorey drift ratios and the stresses in the infill wall decrease with increase in (Ei) values due to increase in stiffness of the model $[1,5]$. It is therefore important to choose the right material for infill, know its properties and consider these in the analysis and design.

b. The minimum compressive strength of infill material required to maintain the structure in an un-cracked condition under a credible earthquake (with $0.2 \mathrm{~g}$ PGA) varies with the height of the building [5]. It has been shown that under exposure to similar seismic hazards, medium rise buildings require higher strength infill material (compared to low rise building).

\begin{tabular}{|c|c|c|c|c|}
\hline Earthquake Load & $\begin{array}{l}\text { Sway for Corner Column } \\
\qquad(\mathrm{mm})\end{array}$ & $\begin{array}{l}\text { Sway for Exterior Column } \\
(\mathbf{m m})\end{array}$ & $\begin{array}{l}\text { Sway for Interior Column } \\
\qquad(\mathrm{mm})\end{array}$ & $\begin{array}{l}\text { Maximum Value of Sway } \\
\qquad(\mathrm{mm})\end{array}$ \\
\hline From Left to Right without Infill & 54.3 & 54.2 & 54.8 & 56.6 \\
\hline From Left to Right with Infill & 32.3 & 32.2 & 33.0 & 35.7 \\
\hline From Front to Back without Infill & 73.2 & 73.2 & 73.1 & 73.2 \\
\hline From Front to Back with Infill & 37.5 & 37.6 & 37.5 & 37.6 \\
\hline
\end{tabular}

Table 1: Sway characteristics of different columns. 
c. The opening size of the infill has a significant influence on the fundamental period, inter-storey drift ratios, infill stresses and the structural member forces. Generally they increase as the opening size increases, indicating that the decrease in stiffness [5] is more significant than the decrease in mass.

d. Under a particular level of PGA (0.2g), the increase in infill stress [4] is not very significant beyond infill strength of $E i=7500$ $\mathrm{MPa}$. This value could be considered to be the maximum limit of the Young's Modulus of the infill material if the infill walls are used for retrofitting old buildings.

e. The performances of buildings constructed with and without seismic provisions [2] are almost similar if the infill has a minimum value of $5000 \mathrm{MPa}$ for its Young's Modulus (Ei). This is because the structural capacity is greatly influenced by the type of infill walls and the values of their Young's Modulus.

\section{Literature Review}

Muyeed-Ul-Azamand Amanat [1] carried out a work on 'Effect of Infill as a Structural Component on the column Design of Multistoried Building' in which various observations had been made on the infill characteristics. The lateral deflection is reduced significantly in the infilled frame compared to the deflection of the frame without infill. This leads to different steel requirements for frame structures considering infill. In order to understand the behavior of frames and steel requirements of column having brick masonry infill and without infill a finite element investigation is performed by modeling a 10-storied three dimensional building frame [5]. The investigation is done by using the equivalent strut model method. A detailed investigation is performed using various loads and load combinations of the building considering infill and without infill to find out steel requirements and to see the effect of infill in the sway characteristics of the building. It is observed that frames with infill produce much smaller deflections as compared to frames without infill. It is also observed that there is no significant difference in steel requirements of interior column but there is moderate difference in steel requirements in exterior column and significant difference in steel requirements in corner column.

Dorji and Thambiratnam [2] carried out the work on 'Modeling and Analysis of In-filled Frame Structures under seismic loads' in which the seismic response of in-filled frame structures had been studied. In-filled frame structures are commonly used in buildings, even in those located in seismically active regions. Present codes unfortunately, do not have adequate guidance for treating the modeling, analysis and design of in-filled frame structures. Finite Element time history analyses under different seismic records have been carried out and the influence of infill strength, openings and soft storey phenomenon are investigated. Results in terms of tip deflection, fundamental period, inter-storey drift ratio and stresses are presented and they will be useful in the seismic design of in-filled frame structures.

Mahumad et al. [5] carried out the work on 'Study of the Reinforced Concrete Frame with Brick Masonry Infill due to Lateral Loads' in which the behavior of Reinforced Concrete (R.C.) frames with brick masonry infill for various parametric changes have been studied to observe their influences in deformation patterns of the frame. Masonry infill panels have been widely used as interior and exterior partition walls for aesthetic reasons and functional needs. When infill walls are omitted in a particular storey, a soft storey is formed compared to much stiffer other stories. The present study is also aimed at finding out the effect of soft storey on frame structures due to horizontal loading. In both cases of wind and earthquake loads, if number of bay increases, then the deflection eventually decreases. As the storey level of building frame increases, deflection due to lateral loads naturally increases due to additional lateral loads. Deflection increases linearly if the span of bay increases linearly because of linearly increased loads [6].

Kodur et al. [4] carried out the work on 'Seismic design and analysis of masonry-infilled frames' in which a simple analytical procedure, which can be used by practicing engineers, for the seismic design of masonryinfilled frames is presented. The analytical procedure, based on the experimental and analytical studies reported in the literature, accounts for the effect of infill's in all three stages, namely, in computing seismic loading, in predicting response of the infilled frame, and in determining the strength of the infilled frame. Seismic loading is computed using the dynamic properties of the structure. Recommendations regarding the choice of infilled frame idealization, structural damping ratio, earthquake design spectrum, structural irregularity, and computational aids are made. Application of the proposed analytical procedure in a design situation is demonstrated through a numerical example, and it is shown that infill's can be accounted in the seismic design of frames during the normal course of design[7].

\section{Methodology}

In most of the analytical works the infill in frame is not considered and it is treated as bare frame. By various literature studies, it is found that the infill has various characteristics like increasing the strength, reducing the deflection, and increasing the stiffness, etc. Hence the work to be done is,

a. By using ETABS software, the framed structures are analyzed including the infill material [8].

b. Computing the structures characteristics for both structures with and without infill

\section{Analysis Method}

\section{Equivalent static analysis}

Equivalent static analysis is the indirect method of considering the effect of ground motion and there is incorporation of dynamic properties of the structure in terms of fundamental period, response reduction factor, soil type, seismic zone and importance factor. Equivalent static analysis were carried out for all the models under the action of Dead Load (DL), Live Load (LL) and Earthquake Load (EQ) for different load combination as per IS 1893-2002 [9].This method is limited to regular type of structure whose response is governed by first mode of vibration. As per IS 1893-2002 regular structure up to $40 \mathrm{~m}$ in height in zone IV and V and up to $90 \mathrm{~m}$ in zone II and III can be analyzed by Time History and Response Spectrum analysis.

\section{Response spectrum method}

The objective of response spectrum analysis is to obtain the likely maximum response of the systems. The response spectrum is a plot of the maximum response (maximum displacement, velocity, acceleration or any other quantity of interest) to a specified load function for all possible single degree-of-freedom systems. The abscissa of the spectrum is the natural period (or frequency) of the system and the ordinate is the maximum response. It is also a function of damping. The design response a spectrum given in IS 1893:2002 for a 5\% damped system.

\section{Time history analysis}

In order to examine the exact non-linear behavior of building structures, nonlinear time history analysis has to be carried out. In 
this method, the structure is subjected to real ground motion records. This makes this analysis method quite different from all of the other approximate analysis methods as the inertial forces are directly determined from these ground motions and the responses of the building either in deformations or in forces are calculated as a function of time, considering the dynamic properties of the building structure.

\section{Pushover analysis}

Pushover analysis is a static, nonlinear procedure in which the magnitude of the lateral forces is incrementally increased, maintaining the predefined distribution pattern along the height of the building. With the increase in magnitude of the loads, weak links and failure modes are found. Pushover analysis can determine the behavior of a building, including the ultimate load and maximum inelastic deflection. Local nonlinear effects are modeled and the structure is pushed until a collapsed mechanism is developed. At each step, the base shear and roof displacement can be plotted to generate the pushover curve.

\section{Conclusion}

- In all the analyses, the infill in the framed members is not considered, but the infill helps in the increase of ductility, stiffness and the flexural strength of the members.

- The behavior of an infilled frame is dependent on the properties of frame and infill; hence, the response of such frames should be based on overall frame to infill composite action rather than on isolated bare frame behavior.

- Effect of dynamic loading on the behavior of masonry infilled R.C. frame may be investigated to determine the characteristics with ease [10].

- The contribution of partial infill walls must be well identified so that while analyzing models for real structures, the composite action of the frame and infill would be realized.

- By considering the infill wall the roof displacement of the structure reduces and the stiffness of the structure increases. The masonry infill wall is more significant in small structures as the height of the structure increases the effect of masonry infill wall reduces.

- The inter-storey drift of all the structural members are within the code prescribed limit of 0.004 . Since the structure becomes stiffer with the decrease in height of structure. By increasing the opening percentage the inter-storey drift also increases.

- In the case of infilled frame with a soft ground storey, the shear forces acting on columns are considerably higher than those obtained from analysis of the bare frame.

- It has been found that calculation of earthquake forces by treating RC frames as ordinary frames without regards to infill leads to underestimation of base shear.

\section{References}

1. Muyeed-Ul-Azam HM, Amanat KM (2005) Effect of Infill as a Structural Component on the Column Design of Multi-storied Building. UAP Journal of Civil and Environmental Engineering.

2. Dorji J, Thambiratnam DP (2009) Modeling and Analysis of Infilled Frame Structures under Seismic Loads. The Open Construction and Building Technology Journal 3: 119-126.

3. Asteris PG (2003) Lateral stiffness of brick masonry infilled plane frames. ASCE J. Str. Engg., 129: 1071-1079.

4. Kodur VR, Erki MA, Quenneville JHP (1995) Seismic design and analysis of masonry-infilled frames. Canadian Journal of Civil Engineering 22: 576-587.

5. Mahmud K, Islam R, Al-Amin (2010) Study of the Reinforced Concrete Frame with Brick Masonry Infill due to Lateral Loads. IJCEE-IJENS.

6. Asteris PG, ASCE M (2003) Lateral Stiffness of Brick Masonry Infilled Plane Frames. Journal of Structural Engineering 129:1071.

7. Pradhan PM, Pradhan PL, Maskey RK (2012) A Review on Partial Infilled Frames under Lateral Loads. Kathmandu University Journal of Science, Engineering and Technology 8: 142-152.

8. ETABS nonlinear Version 9.5.0 Extended 3D analysis of the Building Systems Computers and Structures Inc. 1995 Berkeley, California.

9. Agarwal P, Shrikhande M, Earthquake Resistant Design of structures, Prentice Hall of India Pvt. Ltd., India (2006).

10. Mulgund Gv, Kulkarni AB (2011) Seismic Assessment of RC Frame Buildings with brick masonry infill. IJAEST 2: 140-147. 